\title{
Communication
}

\section{Oxygenated Analogues of Santacruzamate A}

\author{
Plamen Angelov ${ }^{1, *} \mathbb{D}$, Stanimir Manolov ${ }^{1}\left[\mathbb{C}\right.$, Pavel Yanev ${ }^{1}$ and Mladen Naydenov ${ }^{2}$ \\ 1 Department of Organic Chemistry, University of Plovdiv Paisii Hilendarski, 24 Tsar Asen Str., \\ 4000 Plovdiv, Bulgaria; manolov@uni-plovdiv.net (S.M.); qnev@uni-plovdiv.net (P.Y.) \\ 2 Department of Human Anatomy and Physiology, University of Plovdiv Paisii Hilendarski, 24 Tsar Asen Str., \\ 4000 Plovdiv, Bulgaria; naydenov@plantgene.eu \\ * Correspondence: angelov@uni-plovdiv.bg; Tel.: +359-32-261349
}

check for

updates

Citation: Angelov, P.; Manolov, S.; Yanev, P.; Naydenov, M. Oxygenated Analogues of Santacruzamate A. Molbank 2021, 2021, M1188. https://doi.org/10.3390/M1188

Received: 27 January 2021

Accepted: 3 February 2021

Published: 3 February 2021

Publisher's Note: MDPI stays neutral with regard to jurisdictional claims in published maps and institutional affiliations.

Copyright: (c) 2021 by the authors. Licensee MDPI, Basel, Switzerland. This article is an open access article distributed under the terms and conditions of the Creative Commons Attribution (CC BY) license (https:// creativecommons.org/licenses/by/ $4.0 /)$.
Abstract: A new approach for the synthesis of Santacruzamate A analogues is demonstrated. The method allows functionalization at position 3 of the gamma-aminobutyric fragment and carbon chain variation.

Keywords: Santacruzamate A; $\beta$-ketoamide; $\beta$-hydroxyamide

\section{Introduction}

Santacruzamate A (Figure 1a) is a structurally simple natural product isolated from marine cyanobacterium Symploca sp. [1]. This natural product bears some structural similarity to the clinically used histone deacetylase (HDAC) inhibitor vorinostat (SAHA) [2]. The initial publication about its discovery also reported picomolar-level selective inhibitory activity against HDAC2 $\left(\mathrm{IC}_{50}=119 \mathrm{pM}\right)$, with a relatively weak inhibition of HDAC4 and HDAC6 [1]. Although these data were not entirely corroborated by later publications from the same group [3] and others [4-6], the interest drawn by this natural product has led to the preparation of many analogues, some with promising bioactivity [4-8]. Considering the current interest in this topic and the ongoing investigations of the structure-activity relationships, we saw an opportunity to contribute to the availability of structurally diverse Santacruzamate A analogues with our method for $\beta$-keto amide synthesis [9]. In a previous publication we demonstrated that this enamine-based domino approach provides access to $\beta$-keto amides IV functionalized with protected amino group in the side chain (Scheme 1, $\mathrm{R}^{1}=\mathrm{H}, \mathrm{Ph}$ ) [10]. If $\mathrm{N}$-ethoxycarbonyl glycine is used as the amino acid component III in this methodology and $\mathrm{R}^{1}$ is set to phenethyl, then the products IV would be structurally similar to Santacruzamate A, with introduced carbonyl functionality in the gamma-aminobutyric part and possible variation of the chain length by the choice of an appropriate $R^{1}$ substituent in the acetoacetamide I (Figure 1b).<smiles>CCOC(=O)NCCCC(=O)NCCc1ccccc1</smiles>

(a)<smiles>C=CCCCCCCCCCCCCCC(=O)NNC(=O)OCC</smiles>

(b)
Figure 1. Santacruzamate A (a) and oxygenated analogues (b). 


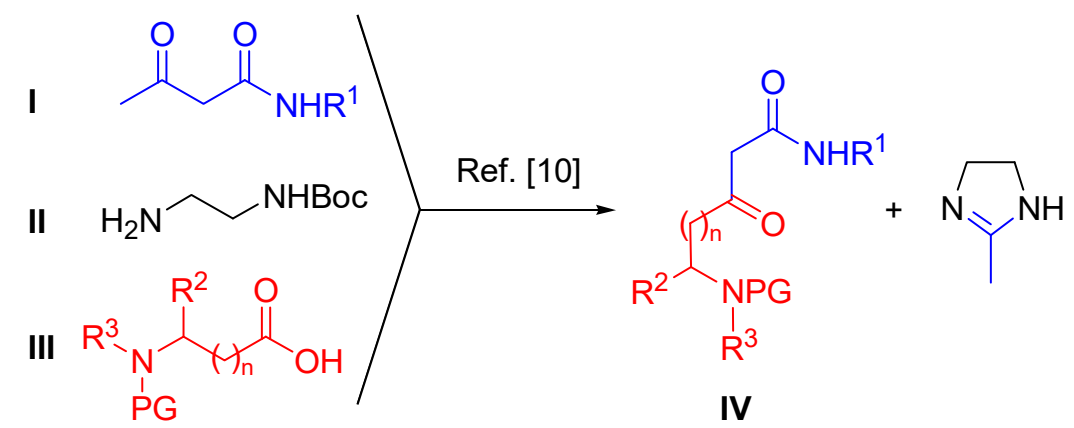

Scheme 1. Synthetic methodology for functionalized $\beta$-keto amides [10].

\section{Results}

To synthesize the oxo-analogue of Santacruzamate A, we first prepared the enaminoamide 2a (Scheme 2, $m=2$ ) by condensation of $N$-phenethyl acetoacetamide with Boc-monoprotected ethylenediamine. This compound was then reacted with mixed carbonic anhydride of $N$-ethoxycarbonyl glycine to provide the intermediate $3 \mathrm{a}$ in $85 \%$ yield. Upon the subsequent Boc-deprotection and buffering with $\mathrm{NaOAc}$ solution, 3a gave the expected analogue $4 \mathrm{a}$ in $80 \%$ yield. By analogy, this procedure was applied for the preparation of $N$-methylated analogue $4 \mathbf{b}$ and chain-shifted analogue $4 c$ (Scheme 2, Table 1). The entire synthetic sequence was carried out without any chromatographic purification of the intermediates. The final step gave practically pure keto amides 4 with only small proportion of the enol tautomer visible in the ${ }^{1} \mathrm{H}$ NMR spectra (Supplementary materials).<smiles>CC(=O)CC(=O)NC(C)C1Oc2ccccc21</smiles>

1

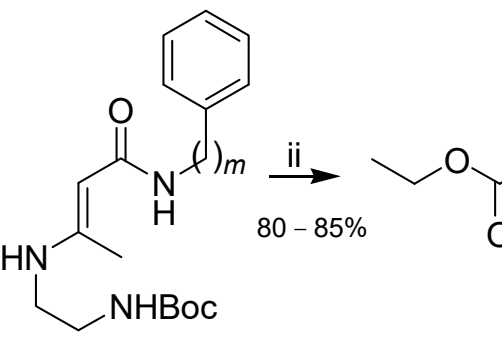

2

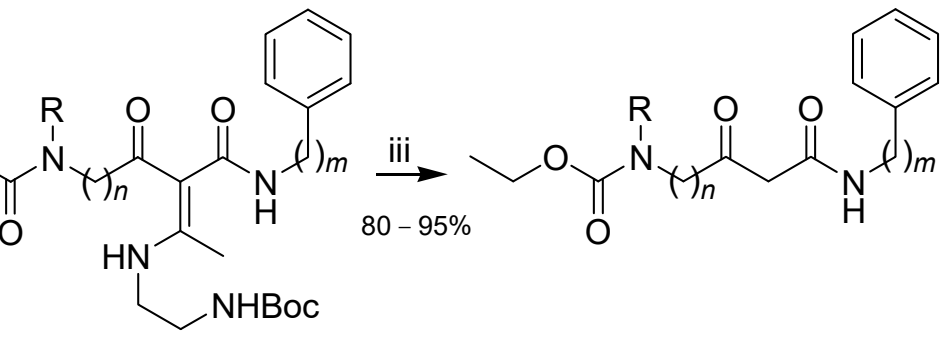

Scheme 2. Reagents and conditions: (i) BocNHCH $\mathrm{CH}_{2} \mathrm{NH}_{2}, \mathrm{CH}_{2} \mathrm{Cl}_{2}, \mathrm{Na}_{2} \mathrm{SO}_{4}, 24$ h r.t.; (ii) $\mathrm{N}$-Ethoxycarbonyl amino acid, $\mathrm{NMM}$, EtOCOCl, $\mathrm{CH}_{2} \mathrm{Cl}_{2}, 0^{\circ} \mathrm{C}, 5 \mathrm{~min}$; Then 2 and DMAP (0.2 equiv.) in $\mathrm{CH}_{2} \mathrm{Cl}_{2}, 0^{\circ} \mathrm{C}$ to r.t., 1 h.; (iii) TFA, 5 min, r.t., then aq. $\mathrm{CH}_{3} \mathrm{COONa}, 2$ h, r.t.

Table 1. Yields of keto amides 4 , prepared according to Scheme 2.

\begin{tabular}{ccccc}
\hline $\mathbf{4}$ & $\boldsymbol{n}$ & $\boldsymbol{m}$ & $\mathbf{R}$ & Yield (\%) $^{\mathbf{1}}$ \\
\hline $\mathbf{a}$ & 1 & 2 & $\mathrm{H}$ & 68 \\
$\mathbf{b}$ & 1 & 2 & $\mathrm{CH}_{3}$ & 76 \\
$\mathbf{c}$ & 2 & 1 & $\mathrm{H}$ & 71 \\
\hline
\end{tabular}

${ }^{1}$ Overall yield after three steps, based on the starting acetoacetamide $\mathbf{1 .}$

The introduction of carbonyl group in the gamma-aminobutyric fragment of Santacruzamate A provides a useful handle for various further manipulations. For example, the reduction of $4 \mathbf{a}, \mathbf{b}$ with $\mathrm{NaBH}_{4}$ was straightforward and gave the corresponding alcohols $\mathbf{5 a}, \mathbf{b}$ in quantitative yields (Scheme 3 ). 


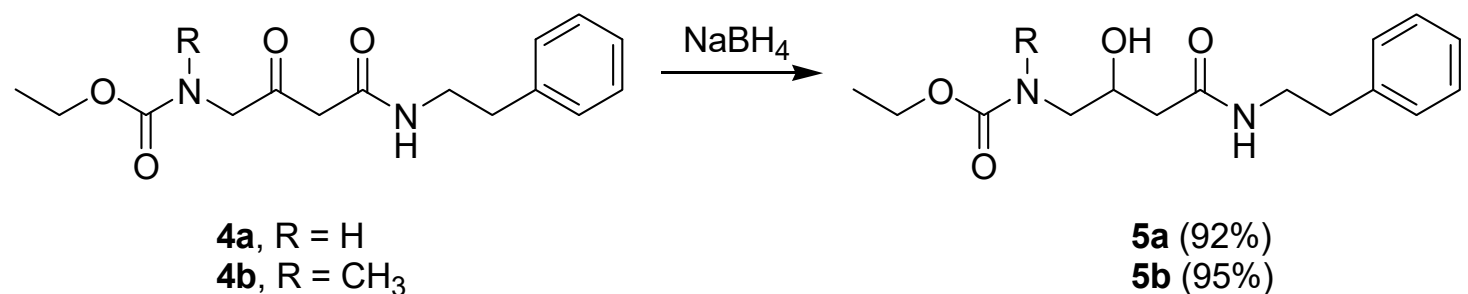

Scheme 3. Reduction of oxo-analogues to hydroxy-analogues.

\section{Materials and Methods}

All reagents and solvents were purchased from commercial suppliers (Sigma-Aldrich or Merck, Darmstadt, Germany) and were used without further purification. Boc-monoprotected ethylenediamine [11], acetoacetamides $\mathbf{1}$ [12,13], and enaminoamides 2 [9] were prepared according to the published procedures. NMR spectra were run on Bruker Avance AV600 $\left(600 / 150 \mathrm{MHz}{ }^{1} \mathrm{H} /{ }^{13} \mathrm{C}\right)$ spectrometer (Bruker, Billerica, MA, USA) at BAS-IOCCP-Sofia and chemical shifts $(\delta, \mathrm{ppm})$ are downfield from TMS. High resolution mass spectral measurements were performed on a Thermo Scientific $Q$ Exactive hybrid quadrupoleorbitrap mass spectrometer (Thermo Fisher Scientific, Waltham, MA, USA). TLC was done on aluminium-backed Silica gel 60 sheets (Merck) with $\mathrm{KMnO}_{4}$ staining; Melting points were measured on Boetius hot stage apparatus (Boetius, Germany) and are not corrected.

\section{Synthetic Procedures}

Oxo-analogues of Santacruzamate A (4a-c), general procedure: To a magnetically stirred solution of the corresponding $N$-ethoxycarbonyl amino acid $(1 \mathrm{mmol})$ in $\mathrm{CH}_{2} \mathrm{Cl}_{2}(5 \mathrm{~mL})$, $\mathrm{N}$-methylmorpholine ( $1 \mathrm{mmol}, 0.11 \mathrm{~mL}$ ) was added. The solution was then put in an ice bath and ethyl chloroformate $(1 \mathrm{mmol}, 0.1 \mathrm{~mL})$ was added. The mixture was left to stir for $5 \mathrm{~min}$ and after that a solution of enamino amide $2(1 \mathrm{mmol})$ and DMAP $(0.2 \mathrm{mmol})$ in $\mathrm{CH}_{2} \mathrm{Cl}_{2}(10 \mathrm{~mL})$ was added in one go. The ice bath was then removed, and the reaction mixture was left to stir for one more hour at r.t. The reaction mixture was then transferred to a separatory funnel with additional $30 \mathrm{~mL}$ of $\mathrm{CH}_{2} \mathrm{Cl}_{2}$ and washed with aqueous (10:1) $\mathrm{HCl}$. The aqueous layer was extracted with 30 more $\mathrm{mL}$ of $\mathrm{CH}_{2} \mathrm{Cl}_{2}$, the combined organic layers were dried with anhydrous sodium sulfate, the drying agent was removed by filtration, and the solvent was evaporated under reduced pressure. The intermediates 3 solidified upon trituration with small volume of diethyl ether. The ethereal washings were filtered off and the crude compounds 3 were dissolved in TFA ( $1 \mathrm{~mL}$ TFA per $100 \mathrm{mg}$ of 3 ). The TFA solutions were stirred for $5 \mathrm{~min}$ at r.t. and then $3 \mathrm{~mol} / \mathrm{L}$ aqueous solution of $\mathrm{NaOAc}$ (10 mL for each mL of TFA) was added, followed by $\mathrm{CH}_{2} \mathrm{Cl}_{2}(30-50 \mathrm{~mL})$. The mixture was left to stir intensely for $2 \mathrm{~h}$. The layers were then separated, and the aqueous layer was extracted two more times with $\mathrm{CH}_{2} \mathrm{Cl}_{2}$. The organic layers were combined, washed with saturated aqueous $\mathrm{NaHCO}_{3}(20 \mathrm{~mL})$, and then dried over $\mathrm{Na}_{2} \mathrm{SO}_{4}$. The solvent was removed on a rotary evaporator. Compounds $4 \mathbf{a}$ and $4 \mathbf{c}$ crystallized and were rinsed with small volumes of diethyl ether or ether-petroleum. Compound $\mathbf{4 b}$ was isolated as clear oil. Chromatography of the ethereal washings through a short plug of silica gel can afford small additional amounts of $4 \mathbf{a}, \mathbf{c}$.

(2-Oxo-3-phenethylcarbamoyl-propyl)-carbamic acid ethyl ester (4a): white solid, mp 137 $-139{ }^{\circ} \mathrm{C} ; \mathrm{R}_{\mathrm{f}}=0.55\left(\mathrm{Et}_{2} \mathrm{O}: \mathrm{CH}_{3} \mathrm{OH} 20: 1\right) ;{ }^{1} \mathrm{H}-\mathrm{NMR}\left(600 \mathrm{MHz}, \mathrm{CDCl}_{3}, \delta \mathrm{ppm}, J \mathrm{~Hz}\right): 7.34-7.20$ $(\mathrm{m}, 5 \mathrm{H}), 6.71(\mathrm{br} \mathrm{s}, 1 \mathrm{H}), 5.40(\mathrm{br} \mathrm{s}, 1 \mathrm{H}), 4.15(\mathrm{q}, J=7.0,2 \mathrm{H})$ overlapped with $4.12(\mathrm{~d}, J=5.3$, $2 \mathrm{H}), 3.55(\mathrm{dt}, J=6.4, J=7.0,2 \mathrm{H}), 3.39(\mathrm{~s}, 2 \mathrm{H}), 2.84(\mathrm{t}, J=7.0,2 \mathrm{H}), 1.27(\mathrm{t}, J=7.0,3 \mathrm{H})$; ${ }^{13} \mathrm{C}-\mathrm{NMR}\left(150 \mathrm{MHz}, \mathrm{CDCl}_{3}, \delta \mathrm{ppm}\right): 201.6,164.8,156.5,138.6,128.8,128.7,126.6,61.4$, 51.1, 47.0, 40.9, 35.5, 14.6; ESI-MS $(m / z): 315.1320[\mathrm{M}+\mathrm{Na}]^{+}$(calcd for $\mathrm{C}_{15} \mathrm{H}_{20} \mathrm{~N}_{2} \mathrm{NaO}_{4}{ }^{+}$ 315.1315); 291.1353 [M - H] ${ }^{-}$(calcd for $\mathrm{C}_{15} \mathrm{H}_{19} \mathrm{~N}_{2} \mathrm{O}_{4}{ }^{-}$291.1350).

Methyl-(2-oxo-3-phenethylcarbamoyl-propyl)-carbamic acid ethyl ester (4b): clear oil; $\mathrm{R}_{\mathrm{f}}=0.35$ $\left(\mathrm{Et}_{2} \mathrm{O}: \mathrm{CH}_{3} \mathrm{OH} 20: 1\right) ;{ }^{1} \mathrm{H}-\mathrm{NMR}\left(600 \mathrm{MHz}, \mathrm{CDCl}_{3}, \delta \mathrm{ppm}, J \mathrm{~Hz}\right)$, only signals for the major rotamer are listed: 7.34-7.21 (m, 5H), $6.87(\mathrm{br} \mathrm{s}, 1 \mathrm{H}), 4.17-4.09(\mathrm{~m}, 4 \mathrm{H}) 3.55(\mathrm{~m}, 2 \mathrm{H}), 3.38$ 
$(\mathrm{s}, 2 \mathrm{H}), 2.94(\mathrm{~s}, 3 \mathrm{H}), 2.85(\mathrm{t}, J=7.0,2 \mathrm{H}), 1.30(\mathrm{t}, J=7.0,3 \mathrm{H}) ;{ }^{13} \mathrm{C}-\mathrm{NMR}\left(150 \mathrm{MHz}, \mathrm{CDCl}_{3}\right.$, $\delta$ ppm): 202.0, 165.1, 157.0, 138.7, 128.8, 128.6, 126.6, 62.0, 58.9, 46.7, 41.0, 35.6, 35.5, 14.6; ESI-MS ( $m / z)$ : $329.1475[\mathrm{M}+\mathrm{Na}]^{+}$(calcd for $\mathrm{C}_{16} \mathrm{H}_{22} \mathrm{~N}_{2} \mathrm{NaO}_{4}{ }^{+} 329.1472$ ).

(4-Benzylcarbamoyl-3-oxo-butyl)-carbamic acid ethyl ester (4c): white solid, mp 100-102 ${ }^{\circ} \mathrm{C}$; $\mathrm{R}_{\mathrm{f}}=0.50\left(\mathrm{Et}_{2} \mathrm{O}: \mathrm{CH}_{3} \mathrm{OH} 20: 1\right) ;{ }^{1} \mathrm{H}-\mathrm{NMR}\left(600 \mathrm{MHz}, \mathrm{DMSO}-\mathrm{d}_{6}, \delta \mathrm{ppm}, J \mathrm{~Hz}\right): 8.33$ (br $\mathrm{t}$, $J=5.9,1 \mathrm{H}), 7.15-7.04(\mathrm{~m}, 5 \mathrm{H}), 6.86($ br t $, J=5.9,1 \mathrm{H}), 4.10(\mathrm{~d}, J=5.9,2 \mathrm{H}) 3.77(\mathrm{q}, J=7.0,2 \mathrm{H})$ $3.21(\mathrm{~s}, 2 \mathrm{H}), 2.98(\mathrm{dt}, J=5.9, J=7.0,2 \mathrm{H}), 2.50(\mathrm{t}, J=7.0,2 \mathrm{H}), 0.95(\mathrm{t}, J=7.0,3 \mathrm{H}) ;{ }^{13} \mathrm{C}-\mathrm{NMR}$ (150 MHz, DMSO- $d_{6}, \delta$ ppm): 204.3, 166.5, 156.6, 139.6, 128.8, 127.7, 127.3, 60.0, 50.9, 42.9, 42.7, 35.7, 15.1; ESI-MS ( $m / z)$ : $315.1317[\mathrm{M}+\mathrm{Na}]^{+}\left(\right.$calcd for $\mathrm{C}_{15} \mathrm{H}_{20} \mathrm{~N}_{2} \mathrm{NaO}_{4}{ }^{+}$315.1315);

Hydroxy-analogues of Santacruzamate A (5): To the corresponding keto amide 4 (100 mg) in methanol $(10 \mathrm{~mL})$ was added $\mathrm{NaBH}_{4}$ in small portions (5-7 mg every $10 \mathrm{~min}$ ) until TLC indicated the absence of the starting material. The mixture was then diluted with water $(50 \mathrm{~mL})$ and extracted with $\mathrm{CH}_{2} \mathrm{Cl}_{2}(3 \times 20 \mathrm{~mL})$. The organic layers were combined, dried over $\mathrm{Na}_{2} \mathrm{SO}_{4}$, and the solvent was removed on a rotary evaporator to afford practically clean hydroxy amides 5 .

(2-Hydroxy-3-phenethylcarbamoyl-propyl)-carbamic acid ethyl ester (5a): white solid, $\mathrm{mp}$ 104-105 ${ }^{\circ} \mathrm{C} ; \mathrm{R}_{\mathrm{f}}=0.50\left(\mathrm{Et}_{2} \mathrm{O}: \mathrm{CH}_{3} \mathrm{OH} 20: 1\right) ;{ }^{1} \mathrm{H}-\mathrm{NMR}\left(600 \mathrm{MHz}, \mathrm{CDCl}_{3}, \delta \mathrm{ppm}, \mathrm{J} \mathrm{Hz}\right): 7.25-$ $7.11(\mathrm{~m}, 5 \mathrm{H}), 6.20$ (br s, 1H), $5.24(\mathrm{br} \mathrm{s}, 1 \mathrm{H}), 4.02(\mathrm{q}, J=7.0,2 \mathrm{H}), 3.96(\mathrm{~m}, 1 \mathrm{H}), 3.45(\mathrm{dt}, J=5.9$, $J=7.0,2 \mathrm{H}), 3.22\left(\mathrm{dt},{ }^{2} J=14.1,{ }^{3} \mathrm{~J}=4.7,1 \mathrm{H}\right), 3.09\left(\mathrm{dt},{ }^{2} \mathrm{~J}=14.1,{ }^{3} \mathrm{~J}=5.9,1 \mathrm{H}\right), 2.75(\mathrm{t}, J=7.0$, 2H), $2.24(\mathrm{~m}, 2 \mathrm{H}), 1.16(\mathrm{t}, J=7.0,3 \mathrm{H}) ;{ }^{13} \mathrm{C}-\mathrm{NMR}\left(150 \mathrm{MHz}, \mathrm{CDCl}_{3}, \delta \mathrm{ppm}\right): 172.04,157.6$, 138.6, 128.74, 128.70, 126.6, 68.2, 61.1, 45.9, 40.6, 39.6, 35.5, 14.6; ESI-MS (m/z): 317.1475 $[\mathrm{M}+\mathrm{Na}]^{+}$(calcd for $\mathrm{C}_{15} \mathrm{H}_{22} \mathrm{~N}_{2} \mathrm{NaO}_{4}{ }^{+} 317.1472$ ).

(2-Hydroxy-3-phenethylcarbamoyl-propyl)-methyl-carbamic acid ethyl ester (5b): white solid, mp 79-81 ${ }^{\circ} \mathrm{C} ; \mathrm{R}_{\mathrm{f}}=0.33\left(\mathrm{Et}_{2} \mathrm{O}: \mathrm{CH}_{3} \mathrm{OH} 20: 1\right) ;{ }^{1} \mathrm{H}-\mathrm{NMR}\left(600 \mathrm{MHz}, \mathrm{CDCl}_{3}, \delta \mathrm{ppm}, \mathrm{J} \mathrm{Hz}\right)$, only signals for the major rotamer are listed: 7.33-7.21 (m, 5H), 6.47 (br s, 1H), 4.15 (br s, 1H) overlapped with $4.13(\mathrm{q}, J=7.0,2 \mathrm{H}), 3.55(\mathrm{~m}, 2 \mathrm{H}), 3.33(\mathrm{~m}, 2 \mathrm{H}), 2.99(\mathrm{~s}, 3 \mathrm{H}), 2.84(\mathrm{t}, J=7.0$, $2 \mathrm{H}), 2.33(\mathrm{~m}, 2 \mathrm{H}), 1.28(\mathrm{t}, J=7.0,3 \mathrm{H}) ;{ }^{13} \mathrm{C}-\mathrm{NMR}\left(150 \mathrm{MHz}, \mathrm{CDCl}_{3}, \delta \mathrm{ppm}\right): 171.9,158.0$, 138.7, 128.8, 128.6, 126.6, 68.2, 61.8, 54.6, 40.6, 40.2, 36.2, 35.6, 14.7; ESI-MS ( $\mathrm{m} / \mathrm{z}): 331.1630$ $[\mathrm{M}+\mathrm{Na}]^{+}$(calcd for $\mathrm{C}_{16} \mathrm{H}_{24} \mathrm{~N}_{2} \mathrm{NaO}_{4}{ }^{+} 331.1628$ ).

\section{Conclusions}

We successfully prepared new oxygenated analogues of Santacruzamate A. This extends the scope of the enamine-based domino approach to functionalized $\beta$-keto amides and demonstrates a viable route to many more analogues of the natural product.

Supplementary Materials: The following are available online, S1.PDF-processed ${ }^{1} \mathrm{H}$ and ${ }^{13} \mathrm{C}$ NMR spectra. S2.zip—Raw NMR data. S3.zip—mol files.

Author Contributions: Conceptualization, chemical synthesis, and manuscript writing: P.A.; chemical synthesis: S.M. and P.Y.; High resolution mass spectral measurements: M.N. All authors have read and agreed to the published version of the manuscript.

Funding: This research was funded by Bulgarian National Science Fund, grant number DN0915/2016 and The University of Plovdiv, grant number HF19-MU-012. P.Y. acknowledges support from Bulgarian Ministry of Education and Science under the National Research Programme "Young scientists and postdoctoral students" 577/17.08.2018.

Data Availability Statement: The data presented in this study are available in this article and supporting supplementary material.

Acknowledgments: The authors are grateful to the Faculty of Biology, Department of Plant Physiology and Molecular Biology for access to high resolution mass spectrometer, provided under the EC FP7/REGPOT-2009-1/BioSupport project.

Conflicts of Interest: The authors declare no conflict of interest. 


\section{References}

1. Pavlik, C.M.; Wong, C.Y.B.; Ononye, S.; Lopez, D.D.; Engene, N.; McPhail, K.L.; Gerwick, W.H.; Balunas, M.J. Santacruzamate A, a Potent and Selective Histone Deacetylase Inhibitor from the Panamanian Marine Cyanobacterium cf. Symploca sp. J. Nat. Prod. 2013, 76, 2026-2033. [CrossRef] [PubMed]

2. Marks, P.A. Discovery and development of SAHA as an anticancer agent. Oncogene 2007, 26, 1351-1356. [CrossRef]

3. Gromek, S.M.; deMayo, J.A.; Maxwell, A.T.; West, A.M.; Pavlik, C.M.; Zhao, Z.; Li, J.; Wiemer, A.J.; Zweifach, A.; Balunas, M.J. Synthesis and biological evaluation of santacruzamate A analogues for anti-proliferative and immunomodulatory activity. Bioorg. Med. Chem. 2016, 24, 5183-5196. [CrossRef] [PubMed]

4. Liu, Q.; Lu, W.; Ma, M.; Liao, J.; Ganesan, A.; Hu, Y.; Wen, S.; Huang, P. Synthesis and biological evaluation of santacruzamate A and analogs as potential anticancer agents. RSC Adv. 2015, 5, 1109-1112. [CrossRef]

5. Randino, R.; Gazzerro, P.; Mazitschek, R.; Rodriquez, M. Synthesis and biological evaluation of Santacruzamate-A based analogues. Bioorg. Med. Chem. 2017, 25, 6486-6491. [CrossRef] [PubMed]

6. Krieger, V.; Hamacher, A.; Gertzen, C.G.W.; Senger, J.; Zwinderman, M.R.H.; Marek, M.; Romier, C.; Dekker, F.J.; Kurz, T.; Jung, M.; et al. Design, Multicomponent Synthesis, and Anticancer Activity of a Focused Histone Deacetylase (HDAC) Inhibitor Library with Peptoid-Based Cap Groups. J. Med. Chem. 2017, 60, 5493-5506. [CrossRef] [PubMed]

7. Andrade, S.N.; Evangelista, F.C.G.; Seckler, D.; Marques, D.R.; Freitas, T.R.; Nunes, R.R.; Oliveira, J.T.; Ribeiro, R.I.M.A.; Santos, H.B.; Thomé, R.G.; et al. Synthesis, cytotoxic activity, and mode of action of new Santacruzamate A analogs. Med. Chem. Res. 2018, 27, 2397-2413. [CrossRef]

8. Balunas, M.J.; Pavlik, C.M.; Gerwick, G.H. Santacruzamate A compositions and analogs and methods of use. Patent WO2014018913A2, 30 January 2014. Available online: https:/ / patents.google.com/patent/WO2014018913A2/en. (accessed on 1 January 2021).

9. Angelov, P. Enamine-Based Domino Strategy for C-Acylation/Deacetylation of Acetoacetamides: A Practical Synthesis of $\beta$-Keto Amides. Synlett 2010, 1273-1275. [CrossRef]

10. Yanev, P.; Angelov, P. Synthesis of functionalised $\beta$-keto amides by aminoacylation/domino fragmentation of $\beta$-enamino amides. Beilstein J. Org. Chem. 2018, 14, 2602-2606. [CrossRef] [PubMed]

11. Kofoed, T.; Hansen, H.F.; Ørum, H.; Koch, T. PNA synthesis using a novel Boc/acyl protecting group strategy. J. Pept. Sci. 2001, 7, 402-412. [CrossRef] [PubMed]

12. Clemens, R.J.; Hyatt, J.A. Acetoacetylation with 2,2,6-trimethyl-4H-1,3-dioxin-4-one: A convenient alternative to diketene. J. Org. Chem. 1985, 50, 2431-2435. [CrossRef]

13. Witzeman, J.S.; Nottingham, W.D. Transacetoacetylation with tert-butyl acetoacetate: Synthetic applications. J. Org. Chem. 1991, 56, 1713-1718. [CrossRef] 